\title{
ALTERNATIF STRATEGI PEMBIAYAAN ASURANSI BENCANA ALAM DI INDONESIA
}

\section{ALTERNATIVE NATURAL DISASTER INSURANCE FINANCING STRATEGIES IN INDONESIA}

\begin{tabular}{|c|c|}
\hline $\begin{array}{l}\text { Ellectrananda } \\
\text { Anugerah Ash- } \\
\text { Shidiqqi } \\
\text { Universitas Slamet } \\
\text { Riyadi Surakarta, } \\
\text { ndonesia } \\
\text { email: } \\
\text { ellectra aa@yahoo.co } \\
\text { id }\end{array}$ & $\begin{array}{l}\text { Abstrak: Indonesia memiliki potensi bencana alam dengan intensitas } \\
\text { kejadian bencana alam yang tinggi serta memiliki potensi kerugian } \\
\text { yang cukup tinggi. Proses penanggulangan bencana yang diatur dalam } \\
\text { Undang-undang Nomor } 24 \text { Tahun } 2007 \text { tentang Penanggulangan } \\
\text { Bencana masih memiliki kelemahan-kelemahan yakni belum } \\
\text { terwujudnya regulasi turunan undang-undang penanggulangan } \\
\text { bencana, belum optimalnya dukungan anggaran bencana, lambatnya } \\
\text { mekanisme proses dana penanggulangan bencana, lambatnya upaya } \\
\text { mitigasi dan tanggap darurat bencana, dan lemahnya koordinasi antar } \\
\text { instansi terkait. Kelemahan tersebut membuat lama dan semakin } \\
\text { meningkatnya kerugian yang ditimbulkan sehingga semakin } \\
\text { menambah beban akibat bencana alam. } \\
\text { Kata Kunci: Indonesia, Bantuan Bencana Alam, Percepatan. } \\
\text { Abstract: Indonesia has the potential for natural disasters with a high } \\
\text { intensity of natural disasters and has a fairly high potential for losses. } \\
\text { The disaster management process regulated in Law Number } 24 \text { of } 2007 \\
\text { concerning Disaster Management still has weaknesses, namely the } \\
\text { absence of derivative regulations for disaster management, not yet } \\
\text { optimal support for disaster budgets, slow mechanism for disaster } \\
\text { management funds, slow mitigation and response efforts. disaster } \\
\text { emergencies, and weak coordination between relevant agencies. These } \\
\text { weaknesses make the length of time and the losses incurred are } \\
\text { increasing so that it adds to the burden of natural disasters. } \\
\text { Keywords: Indonesia, Natural Disaster Relief, Acceleration }\end{array}$ \\
\hline
\end{tabular}

\section{PENDAHULUAN}

Indonesia adalah salah satu negara yang memiliki risiko tinggi akibat dampak bencana alam yang mengakibatkan kerugian ekonomi, kerugian fisik dan jumlah korban jiwa yang besar. Indonesia termasuk dalam daftar 35 negara di dunia dengan risiko tinggi terjadinya korban jiwa akibat dari dampak berbagai jenis bencana. Tingginya risiko dikarenakan lebih dari 200 juta penduduk tinggal di daerah rawan bencana. Risiko tersebut antara lain juga disebabkan oleh kualitas infrastruktur publik dan non publik yang tidak tahan terhadap bencana.

Hampir seluruh wilayah di Indonesia terpapar risiko atas sembilan bencana alam utama, yaitu gempa bumi, tsunami, banjir, tanah longsor, letusan gunung api, kebakaran, cuaca ekstrim, gelombang ekstrim, dan kekeringan. Beberapa bencana alam terjadi dengan intensitas kejadian yang tinggi, seperti banjir dan tanah longsor. Pada periode tahun 2000 sampai dengan 2016, setiap tahunnya rata-rata kerugian ekonomi langsung 
akibat rusaknya bangunan dan bukan bangunan akibat bencana alam yang terjadi di Indonesia mencapai sekitar Rp. 22,8.

Satu kejadian bencana alam besar, seperti gempa bumi dan tsunami di Pulau Sumatera bagian utara pada tahun 2004, menimbulkan kerugian ekonomi sekitar Rp. 51,4 triliun. Sementara itu, gempa bumi di Daerah Istimewa Yogyakarta pada tahun 2006 menimbulkan kerugian ekonomi senilai Rp. 26,1 triliun. Nilai kerugian ekonomi yang tercatat biasanya tidak mencerminkan kerugian yang sesungguhnya terjadi.

Bank Dunia memperkirakan kerugian ekonomi yang dapat diidentifikasi akibat bencana alam hanya menggambarkan sekitar $60 \%$ dari nilai kerugian ekonomi yang sesungguhnya terjadi. Kondisi ini menjadikan kebijakan penanggulangan bencana, termasuk di dalamnya kebijakan pengurangan risiko bencana dan pembiayaan dalam mendukung upaya mitigasi dan kesiapsiagaan Pemerintah dan masyarakat, menjadi salah satu prioritas Pemerintah. Rencana Pembangunan Jangka Panjang Nasional (RPJPN) 2005-2025 mencantumkan program penanggulangan bencana sebagai bagian dari delapan misi pembangunan nasional. Agenda penanggulangan bencana juga tercantum pada Rencana Pembangunan Jangka Menengah Nasional (RPJMN) 2010-2014 dan RPJMN 2015-2019.

Di samping itu, secara khusus pemerintah telah menerbitkan Rencana Nasional Penanggulangan Bencana (Renas PB) secara berkala, dengan Renas PB terakhir mencakup periode 2015-2019. Renas PB 2015-2019 mencanangkan visi "Menjadikan Bangsa yang Tangguh Menghadapi Bencana" dengan empat misi yaitu: (1) membangun efektivitas dalam upaya pengurangan risiko bencana pada kawasan yang memiliki risiko bencana, terutama pada pusatpusat pertumbuhan pembangunan; (2) meningkatkan efektivitas penanganan tanggap darurat; (3) melakukan optimalisasi dan percepatan pemulihan wilayah pascabencana dan masyarakat yang terkena bencana untuk lebih mandiri; dan (i4) meningkatkan kemampuan dan akuntabilitas dalam tata kelola penanggulangan bencana.

Rancangan kebijakan dalam RPJMN dan Renas PB sejalan dengan kontrak politik Pemerintah sebagaimana tercantum dalam Nawacita, khususnya pada Nawacita ke-7, yaitu: Mewujudkan kemandirian ekonomi dengan menggerakkan sektor-sektor strategis ekonomi domestik. Kebijakan penanggulangan bencana dalam RPJMN 2015-2019 diarahkan untuk mengurangi risiko bencana dan meningkatkan ketangguhan Pemerintah Pusat, Pemda, dan masyarakat dalam menghadapi bencana. Kesiapan 
Pemerintah Pusat dan Pemda serta masyarakat dalam penanggulangan dan mitigasi bencana berkontribusi bagi perwujudan kemandirian ekonomi.

Pembiayaan penanggulangan bencana adalah bagian dari kebijakan penanggulangan bencana dalam rangka melindungi pemerintah, masyarakat, dan sektor swasta terhadap dampak bencana. Pemerintah Pusat dan Pemda memiliki kewajiban untuk menyediakan dana yang cukup melalui Anggaran Pendapatan dan Belanja Negara (APBN) dan Anggaran Pendapatan dan Belanja Daerah (APBD). Masyarakat dan sektor swasta yang memiliki kemampuan keuangan menyediakan dana untuk melindungi usaha dan aset-aset yang dimiliki terhadap risiko dan dampak bencana. Pembiayaan penanggulangan bencana mencakup pembiayaan untuk periode tidak terjadi bencana (pembiayaan prabencana), pembiayaan tanggap darurat ketika terjadi bencana, dan pembiayaan rehabilitasi dan rekonstruksi yang dilakukan setelah selesainya masa tanggap darurat (pembiayaan pasca bencana).

Pembiayaan pada saat darurat bencana tidak sebesar pembiayaan pada tahap rehabilitasi dan rekonstruksi, namun pembiayaan untuk tanggap darurat bencana perlu disediakan dan didistribusikan dengan cepat dan tepat kepada korban bencana. Tahap rekonstruksi memerlukan pembiayaan terbesar dengan durasi waktu lebih panjang untuk pembangunan kembali infrastruktur yang rusak dan hancur. Pembiayaan prabencana dimaksudkan untuk membiayai kegiatan atau program pada masa tidak terjadi bencana dan pada masa terdapat potensi bencana. Pembiayaan pada masa tidak terjadi bencana digunakan antara lain untuk kegiatan atau program pengurangan risiko bencana, program pencegahan bencana, edukasi bencana dan pembiayaan transfer risiko bencana untuk keperluan tersedianya dana di saat terjadi bencana di masa akan datang. Sedangkan pembiayaan ketika terjadi potensi bencana digunakan untuk kegiatan kesiapsiagaan, pembangunan sistem peringatan dini, dan kegiatan mitigasi bencana. Pembiayaan yang digunakan untuk kegiatan pada masa prabencana sebagian besar telah disediakan dalam APBN dalam bentuk alokasi dana untuk K/L terkait. Namun, pembiayaan transfer risiko bencana seperti asuransi belum sepenuhnya diatur secara komprehensif dan sesuai kebutuhan. Skema pembiayaan asuransi yang ada lebih ditujukan untuk mendukung program dari anggaran untuk pembiayaan transfer risiko juga masih jauh dari jumlah yang memadai. Beberapa program bantuan Pemerintah Pusat untuk transfer risiko berwujud subsidi premi asuransi untuk perlindungan masyarakat, rumah tangga dan usaha kecil pada Asuransi Usaha Tani Padi (AUTP), 
Asuransi Usaha Ternak Sapi (AUTS), Asuransi Nelayan Tangkap, dan Asuransi Budidaya Ikan Kecil. Namun, skema-skema pembiayaan tersebut belum dikemas dalam kerangka pembiayaan risiko terhadap bencana. Program subsidi premi asuransi sebesar 80\% untuk petani padi dengan lahan kurang dari 2 hektar, digunakan untuk perlindungan lahan pertanian terhadap risiko gagal panen yang disebabkan oleh serangan hama, bencana alam dan dampak perubahan iklim. Sementara itu, Asuransi Nelayan Tangkap didesain sebagai skema perlindungan nelayan terhadap kecelakaan kerja. Status program-program tersebut masih dalam tahap uji coba (pilot project) dengan cakupan yang masih terbatas dan bersifat eksklusif. Hal ini terlihat dari kecilnya proporsi jumlah petani yang mendapat manfaat AUTP, dimana pada tahun 2017 baru 1,5 juta orang petani peserta program Pemerintah yang terlindungi, atau sekitar 3,5\% dari rumah tangga petani yang mencapai sekitar 43 juta. Kondisi yang sama juga terjadi pada peternak yang mengikuti program AUTS berjumlah sekitar 58 ribu orang dengan jumlah sapi sekitar 91.800 ekor. Oleh karena itu, tujuan penelitian ini adalah untuk mengetahui dan menganalisis skema pembiayaan asuransi bencana alam di Indonesia.

\section{METODE}

Jenis penelitian yang digunakan adalah kualitatif, yaitu jenis pendekatan yang berdasarkan tata cara penelitian yang menghasilkan data diskriptif, yaitu apa yang dinyatakan oleh narasumber secara lisan. Karena dalam penelitian ini akan menemukan sebuah konsep yaitu bagaimana skema produk asuransi syariah terhadap risiko bencana alam di Indonesia.Data ini bersifat kualitatif. Data kualitatif ini didasarkan pada isi atau mutu suatu fakta, seperti data-data yang berdasarkan buku-buku, majalah, koran serta artikel yang yang dikumpulkan penulis yang berhubungan dengan masalah yang terkait pada pembahasan penelitian ini yang kemudian di analisa supaya bisa menjawab permasalahan yang ada. Sumber data penelitian ini adalah studi kepustakaan (library research) yaitu dengan mengumpulkan sejumlah buku-buku dan sumber-sumber bacaan lainnya yang berkaitan dengan pembahasan. Penelitian ini bersifat diskriptif analisis. Sesuai dengan permasalahan yang diangkat, maka dalam pengumpulan data penelitian ini penulisan menggunakan pengumpulan data dengan metode penelitian kepustakaan (library reserch) dan wawancara. Kajian pustaka dilakukan untuk mencapai pemahaman yang komprehensif tentang konsep-konsep yang akan dikaji. 
Literatur yang digunakan untuk kajian pustaka adalah buku, majalah, surat kabar, dan beberapa artikel yang berkaitan dan relevan dengan kajian ini.Dalam penelitian ini penulis akan menggunakan penelitian kualitatif yang bersifat diskriptif. Setelah data selesai dikumpulkan dengan lengkap, tahap berikutnya adalah analisis data. Pada tahap ini, data dikerjakan, dideskripsikan, dijelaskan, dan dianalisis sedemikian rupa sampai berhasil menyimpulkan kebenaran-kebenaran yang dapat dipakai untuk menjawab persoalan-persoalan yang diajukan dalam penelitian. Data dalam informasi tersebut akan disajikan dalam bentuk diskriptif analisis yang bertujuan untuk menjelaskan permasalahan sampai menemukan jawaban yang diharapkan dengan disertai alasanalasan.

\section{HASIL DAN DISKUSI}

Tak dapat dipungkiri bahwa Indonesia berada di kawasan cincin api pasifik atau Ring of Fire yang memiliki potensi bencana seperti gempa bumi dan letusan gunung berapi. Kerugian yang ditimbulkan cukuplah besar tiap-tiap kali terjadi bencana. Sayangnya, kemampuan pemerintah dalam menyediakan pembiayaan bencana cenderung terbatas. Dilansir dari data Kemenkeu, tiap tahun rata-rata pemerintah menyediakan dana cadangan bencana sebesar Rp.3,1 triliun (USD 214 juta), padahal kerugian akibat bencana itu sangatlah besar, seperti gempa dan tsunami Aceh di tahun 2004 kerugiannya mencapai Rp.51,4 triliun (USD 3,5 miliar) sehingga butuh waktu lebih dari 5 tahun untuk pemulihan. Kesenjangan pembiayaan tersebut menyebabkan Indonesia terpapar risiko fiskal yang tinggi.

Sebenarnya pemerintah juga telah menyusun Strategi Pembiayaan dan Asuransi Risiko Bencana (PARB) atau Disaster Risk Financing and Insurance (DRFI) dalam rangka mewujudkan bangsa dan masyarakat yang tangguh dalam menghadapi bencana yang diharapkan dapat memenuhi kebutuhan pembiayaan yang besar, terencana, tepat waktu dan sasaran, berkelanjutan, yang dikelola dengan transparan untuk melindungi keuangan negara. Strategi ini perlu didukung oleh sinergi yang kuat antara pemerintah, swasta dan masyarakat dalam pembiayaan risiko bencana.

Terkait dengan hal tersebut diatas, alternatif pembiayaan dengan melibatkan sumber pembiayaan di luar APBN, diantaranya asuransi, sangatlah diperlukan, agar Indonesia memiliki ketahanan atas bencana yang terjadi. Asuransi sangatlah diperlukan 
karenanya program Asuransi Barang Milik Negara (ABMN) juga di inisiasi pemerintah sebagai keterlibatan pihak swasta memenuhi pembiayaan bencana.

Pembiayaan penanggulangan bencana adalah bagian dari kebijakan penanggulangan bencana dalam rangka melindungi pemerintah, masyarakat, dan sektor swasta terhadap dampak bencana. Pemerintah Pusat dan Pemda memiliki kewajiban untuk menyediakan dana yang cukup melalui Anggaran Pendapatan dan Belanja Negara (APBN) dan Anggaran Pendapatan dan Belanja Daerah (APBD). Masyarakat dan sektor swasta yang memiliki kemampuan keuangan menyediakan dana untuk melindungi usaha dan aset-aset yang dimiliki terhadap risiko dan dampak bencana. Pembiayaan penanggulangan bencana mencakup pembiayaan untuk periode tidak terjadi bencana (pembiayaan prabencana), pembiayaan tanggap darurat ketika terjadi bencana, dan pembiayaan rehabilitasi dan rekonstruksi yang dilakukan setelah selesainya masa tanggap darurat (pembiayaan pasca bencana).

\section{Pembiayaan pada Periode Tidak Terjadi Bencana (Prabencana)}

Pembiayaan prabencana dimaksudkan untuk membiayai kegiatan atau program pada masa tidak terjadi bencana dan pada masa terdapat potensi bencana. Pembiayaan pada masa tidak terjadi bencana digunakan antara lain untuk kegiatan atau program pengurangan risiko bencana, program pencegahan bencana, edukasi bencana dan pembiayaan transfer risiko bencana untuk keperluan tersedianya dana di saat terjadi bencana di masa akan datang. Sedangkan pembiayaan ketika terjadi potensi bencana digunakan untuk kegiatan kesiapsiagaan, pembangunan sistem peringatan dini, dan kegiatan mitigasi bencana. Pembiayaan yang digunakan untuk kegiatan pada masa prabencana sebagian besar telah disediakan dalam APBN dalam bentuk alokasi dana untuk K/L terkait. Namun, pembiayaan transfer risiko bencana seperti asuransi belum sepenuhnya diatur secara komprehensif dan sesuai kebutuhan. Skema pembiayaan asuransi yang ada lebih ditujukan untuk mendukung program dari beberapa K/L dan bukan dalam konteks penurunan risiko bencana. Alokasi anggaran untuk pembiayaan transfer risiko juga masih jauh dari jumlah yang memadai.

\section{Pembiayaan Darurat Bencana}

Pembiayaan pada periode ini antara lain digunakan untuk kegiatan penyelamatan, perlindungan, pemenuhan kebutuhan korban bencana, dan pemulihan kembali sarana dan prasarana vital dengan sumber dari APBN dan APBD. Pembiayaan tanggap darurat dilakukan antara lain melalui mekanisme dana cadangan bencana dan alokasi/realokasi 
APBN pada K/L terkait seperti Badan Nasional Penanggulangan Bencana (BNPB), Kementerian Sosial, dan Kementerian Kesehatan. Bantuan donor nasional dan internasional juga digunakan dalam periode ini. Dana cadangan bencana, khususnya dana siap pakai, dapat dicairkan dengan cepat dan mudah antara 1 (satu) sampai dengan 3 (tiga) hari setelah pengajuan karena telah tercatat dalam Daftar Isian Pelaksanaan Anggaran (DIPA) BNPB. Penggunaannya pun tidak dibatasi untuk jenis bencana alam tertentu. Pemerintah dapat pula menyediakan dana pada periode ini dengan mekanisme pengajuan anggaran tambahan.

\section{Pembiayaan Rehabilitasi dan Rekonstruksi (Pascabencana)}

Pembiayaan pascabencana ditujukan untuk membiayai program-program rehabilitasi dan rekonstruksi melalui alokasi dan realokasi APBN/APBD. Kegiatan rehabilitasi yang dibiayai antara lain kegiatan perbaikan lingkungan, pemberian bantuan perbaikan rumah masyarakat, pemulihan sosial dan psikologis, perbaikan prasarana dan sarana, dan peningkatan kondisi sosial, ekonomi, dan budaya. Sementara pembiayaan untuk rekonstruksi digunakan untuk pembangunan kembali prasarana dan sarana publik dan rumah tangga yang rusak atau hancur akibat bencana.

Titik pusat pengelolaan besaran anggaran penanggulangan bencana ada pada BNPB dan Kementerian Keuangan. BNPB ditugasi menetapkan besaran anggaran penanggulangan bencana bagi setiap daerah yang dilanda bencana. Adapun Kementerian Keuangan ditugasi untuk memastikan pagu anggaran penanggulangan bencana dari APBN dapat dicairkan tepat waktu dan mendapatkan izin DPR. Keterbatasanketerbatasan mekanisme proses dana penanggulangan bencana dapat mengurangi kecepatan respons pemerintah untuk memperbaiki dan membangun infrastruktur yang rusak akibat bencana terutama ketika terjadi keadaan darurat bencana. Keterbatasanketerbatasan mekanisme proses dana penanggulangan bencana diantaranya: pertama, berdasarkan Peraturan Menteri Keuangan Nomor 105 Tahun 2013 tentang Mekanisme Pelaksanaan Anggaran Penanggulangan Bencana dana cadangan alokasi anggaran penanggulangan bencana dialokasikan pada DIPA bagian anggaran BNPB dan DIPA anggaran belanja lain-lain (999.08). DIPA anggaran belanja lain-lain (999.08) untuk dana penanggulangan bencana bergantung dari sisa anggaran setelah pos anggaran mandatory spending seperti anggaran transfer ke daerah, anggaran subsidi dan belanja barang serta modal, dan cicilan bunga utang. Mekanisme pencairan 
DIPA Anggaran 999.08 atau belanja tidak terikat ini kurang cepat, karena dana tersebut ada dalam rekening Kementerian Keuangan dan mekanisme pencairannya mengikuti siklus APBN dan membutuhkan proses persetujuan DPR dengan batas-batas kewenangan kepemerintahan.

\section{KESIMPULAN}

Perbedaan karakteristik pendekatan APBN dengan kebutuhan pembiayaan bencana alam membuka peluang bagi upaya perbaikan tata kelola pembiayaan risiko bencana di masa mendatang. Dalam rangka penurunan risiko bencana dan kesiapsiagaan, pembiayaan risiko bencana dapat dilakukan secara terencana baik untuk memindahkan (transfer) risiko maupun menanggung (retain) risiko. Selanjutnya, rigiditas dalam proses anggaran dapat digunakan dalam membantu disiplin perencanaan dan pelaksanaan pembiayaan bencana. Tersedianya informasi bencana dapat membantu pemerintah dalam merencanakan pembiayaan bencana yang lebih sesuai, tepat waktu, dan tepat sasaran. Keterbatasan APBN dalam pembiayaan bencana juga memunculkan peluang bagi Pemerintah, untuk membangun strategi pembiayaan yang menghasilkan manfaat bersama (co-benefit) bagi Pemerintah Pusat, Pemda, masyarakat dan sektor swasta. Pelaksanaan strategi dengan pendekatan menyeluruh akan membantu pencapaian beberapa tujuan pembangunan sekaligus, seperti terwujudnya masyarakat tangguh bencana dengan tujuan pembangunan nasional, ketahanan fiskal, perlindungan sosial, dan adaptasi perubahan iklim.

\section{REFERENSI}

Badan Nasional Penanggulangan Bencana. (2014). Rencana Nasional Penanggulangan Bencana 2015-2019. Jakarta:Renas PB.

Badan Nasional Penanggulangan Bencana. (2018). Penanganan Dampak Gempa Bumi NTB. Jakarta: Graha BNPB.

Kementerian PPN/Bappenas. (2017). Evaluasi Paruh Waktu RPJMN 2015-2019. Jakarta: Bappenas.

Kementerian Keuangan Republik Indonesia.. (2007). Nota Keuangan dan RAPBN. Berbagai Edisi. Jakarta: Kementerian Keuangan Republik Indonesia. Undang-undang Penanggulangan Bencana. Jakarta Republik Indonesia. 2008. 
Peraturan Presiden Nomor 8 Tahun 2008 tentang Pembentukan Badan Nasional Penanggulangan Bencana Republik Indonesia.

Peraturan Menteri Keuangan Nomor 105 Tahun 2013 tentang Mekanisme Pelaksanaan Anggaran Penanggulangan Bencana Republik Indonesia.

Kerangka Ekonomi Makro dan Pokok-Pokok Kebijakan Fiskal Tahun 2019.

Kementerian Keuangan Tempo. 2018. Kerugian dan Kerusakan Akibat Gempa Lombok. Diakses kembali dari https://bisnis.tempo. co/read/1121145/kerugiandankerusakan-akibat-gempa-lombok-capairp-88-triliun/full\&view=ok. Diakses tanggal 18 Juli 2021.

Dinas Sosial. (2018). Prosedur Pengumpulan Uang atau Barang. Diakses kembali dari http://dinsos.jatengprov.go.id/wp-content/

uploads/2018/04/prosedurpengumpulan-uang-atau-barang.pdf. Diakses tanggal 17 Juli 2021. 